\title{
Decline in Emergent and Urgent Care during the COVID-19 Pandemic
}

Dhruv S. Kazi, MD, MSc, MS;1,2,3 Rishi K. Wadhera, MD, MPP, MPhil;1,2,3 Changyu Shen,

PhD;1,2,3 Kalon K. L. Ho, MD, MSc; ${ }^{3}$ Rushad Patell, MD;2,4 Magdy H. Selim, MD, PhD; John Urwin, MD; 1,2,3 Mark L. Zeidel, MD;2,3 Peter Zimetbaum, MD;1,2,3 Kevin Tabb, MD;6 Robert W. Yeh, MD, MSc ${ }^{1,2,3}$

${ }^{1}$ Richard A. and Susan F. Smith Center for Outcomes Research in Cardiology, Division of Cardiology, Beth Israel Deaconess Medical Center, Boston, Massachusetts

2 Department of Medicine, Beth Israel Deaconess Medical Center, Boston, Massachusetts

${ }^{3}$ Harvard Medical School, Boston, Massachusetts

${ }^{4}$ Division of Hematology, Beth Israel Deaconess Medical Center, Boston, Massachusetts

${ }^{5}$ Department of Neurology, Beth Israel Deaconess Medical Center, Boston, Massachusetts

${ }^{6}$ Beth Israel Lahey Health, Cambridge, Massachusetts

\section{Corresponding Author:}

Dhruv S. Kazi, MD, MSc, MS

375 Longwood Ave, $4^{\text {th }}$ Floor

Boston MA, 02215

Email: dkazi@bidmc.harvard.edu

Cell: $858-527-5800$

Word Count: 630 
medRxiv preprint doi: https://doi.org/10.1101/2020.05.14.20096602; this version posted May 18, 2020. The copyright holder for this preprint (which was not certified by peer review) is the author/funder, who has granted medRxiv a license to display the preprint in perpetuity.

All rights reserved. No reuse allowed without permission.

\section{ABSTRACT}

Due to the ongoing coronavirus disease (COVID-19) pandemic, there are concerns that patients may be avoiding care for emergent and urgent health conditions due to fear of contagion or as an unintentional consequence of government orders to postpone "non-essential" services. We therefore sought to evaluate the effect of the COVID-19 pandemic on the number of patient encounters for select emergent or urgent diagnoses at a large tertiary-care academic medical center in Boston. Inpatient diagnoses included acute myocardial infarction (MI) and stroke, and outpatient but urgent diagnoses included new referrals for breast and hematologic malignancies. For each condition, we used a "difference-in-differences" approach to estimate the proportional change in number of encounters during the pandemic (March - April 2020) compared with earlier in the same year (January - February 2020), using equivalent periods in 2019 as a control. After the onset of the pandemic, we observed significant reductions in hospitalizations for MI (difference-in-differences estimate, $0.67 ; 95 \% \mathrm{Cl}, 0.46-0.96 ; \mathrm{P}=0.04$ ) and stroke (difference-indifferences estimate, $0.42 ; 95 \% \mathrm{Cl}, 0.28-0.65 ; \mathrm{P}<0.001$ ) (Table). In the ambulatory setting, there was a reduction in referrals for breast cancer and hematologic cancers, but this did not reach statistical significance until the month after the onset of the pandemic. Our findings suggest an urgent need for public health messaging to ensure that patients continue to seek care for acute emergencies. In addition, decisions by health systems regarding when to reinitiate non-emergent care should carefully factor in the harms of delayed diagnosis and treatment occurring during the COVID-19 pandemic. 
medRxiv preprint doi: https://doi.org/10.1101/2020.05.14.20096602; this version posted May 18, 2020. The copyright holder for this preprint (which was not certified by peer review) is the author/funder, who has granted medRxiv a license to display the preprint in perpetuity.

\section{MANUSCRIPT}

\section{Background}

In early March 2020, the number of confirmed cases of novel coronavirus disease (COVID-19) in Massachusetts began increasing rapidly. In response to the spread, Massachusetts declared a state of emergency on March 10, 2020. Five days later, the Massachusetts Department of Public Health directed all hospitals and ambulatory surgical centers to postpone or cancel any nonessential procedures to focus the use of healthcare resources on pandemic response and conserve personal protective equipment. ${ }^{1}$ Although life-sustaining interventions are explicitly excluded from the order, patients may not be able to distinguish between elective and urgent or emergent problems, and may defer necessary care due to fear of contagion.

\section{Objective}

We therefore sought to evaluate the effect of the COVID-19 pandemic on the number of patient encounters for select emergent or urgent diagnoses at the Beth Israel Deaconess Medical Center, a large tertiary-care academic medical center in Boston.

\section{Methods and Findings}

We selected conditions for which all patients would be expected to seek care under normal circumstances. Inpatient diagnoses included acute myocardial infarction (MI) and stroke, and outpatient but urgent diagnoses included new referrals for breast and hematologic malignancies. We included breast cancer as it is a common malignancy diagnosed by screening procedures and hematologic cancers as they typically present with mild symptoms yet require urgent treatment. For each condition, we used a "difference-in-differences" approach to estimate the proportional change in number of encounters during the pandemic (March - April 2020) compared with earlier 
medRxiv preprint doi: https://doi.org/10.1101/2020.05.14.20096602; this version posted May 18, 2020. The copyright holder for this preprint (which was not certified by peer review) is the author/funder, who has granted medRxiv a license to display the preprint in perpetuity.

All rights reserved. No reuse allowed without permission.

in the same year (January - February 2020), using equivalent periods in 2019 as a control.

Because the effect on referrals for new malignancies may be delayed (as they would be expected to occur after a decline in primary care clinic visits and screening tests), we performed a sensitivity analysis including a 1-month lag for the oncology referrals. As these analyses used de-identified count data collected as part of a systemwide quality improvement initiative, the institutional review board at Beth Israel Deaconess Medical Center deemed the project not to constitute human subjects research.

After the onset of the pandemic, we observed significant reductions in hospitalizations for MI (difference-in-differences estimate, $0.67 ; 95 \% \mathrm{Cl}, 0.46-0.96 ; \mathrm{P}=0.04$ ) and stroke (difference-indifferences estimate, $0.42 ; 95 \% \mathrm{Cl}, 0.28-0.65 ; \mathrm{P}<0.001$ ) (Table). In the ambulatory setting, there was a numerical decline in new oncology referrals starting March 1, 2020, but these did not achieve statistical significance in the base-case analysis. However, in lag analyses that examined the effect on cancer diagnoses starting April 1,2020, there was a significant reduction in referrals for breast cancer (difference-in-differences estimate, 0.35; 95\% $\mathrm{Cl}, 0.21-0.58 ; \mathrm{P}<0.001$ ) and hematologic cancers (difference-in-differences estimate, 0.39; 95\% Cl, 0.22-0.68; $\mathrm{P}<0.001$ ).

\section{Discussion}

We found a marked decline in presentations for emergent cardiovascular conditions during the pandemic. Reductions in MI during the pandemic have also been observed in Italy, ${ }^{2}$ and for STelevation $\mathrm{MI}$ in the $\mathrm{US},{ }^{3}$ but reductions in stroke have not been described before. This decline may be partially due to a true reduction in incident events due to factors such as altered lifestyle and improved air quality during the lockdown. However, Massachusetts has experienced a large increase in at-home mortality during the COVID-19 pandemic, raising concern that people may be deferring necessary care out of fear of contagion, and possibly dying at home. ${ }^{4}$ Furthermore, 
medRxiv preprint doi: https://doi.org/10.1101/2020.05.14.20096602; this version posted May 18, 2020. The copyright holder for this preprint (which was not certified by peer review) is the author/funder, who has granted medRxiv a license to display the preprint in perpetuity.

All rights reserved. No reuse allowed without permission.

short-term lifestyle changes cannot explain the decline in referrals for new diagnoses of malignancies observed in our study, which are likely the result of decreased outpatient cancer screening during this period, due to postponement of in-person primary care visits and screening studies, and delayed referrals. ${ }^{5}$ Given the time-sensitive nature of initiating treatment for these and other life-threatening conditions, urgent efforts are needed to improve public health messaging to ensure that patients continue to seek care for acute emergencies. In addition, decisions by health systems regarding when to reinitiate non-emergent care should carefully factor in the harms of delayed diagnosis and treatment occurring during the COVID-19 pandemic. 


\section{COMPETING INTERESTS}

Authors have disclosed no conflicts of interest.

\section{AUTHOR APPROVAL}

All authors have seen and approved the manuscript prior to submission.

\section{AUTHOR CONTRIBUTIONS}

Conception and design: D. Kazi, R. Wadhera, K. Tabb, R. Yeh.

Drafting of the article: D. Kazi.

Critical revision of the article for important intellectual content: D. Kazi, R. Wadhera, C. Shen, K. Ho, R. Patell, M Selim, J Urwin, M Zeidel, P Zimetbaum, K Tabb, R Yeh.

Final approval of the article: D. Kazi, R. Wadhera, C. Shen, K. Ho, R. Patell, M Selim, J Urwin, M Zeidel, P Zimetbaum, K Tabb, R Yeh.

Administrative, technical, or logistic support: D. Kazi.

\section{PRIMARY FUNDING SOURCE}

None.

\section{DATA AVAILABILITY STATEMENT}

All encounter data used in the analyses are presented in the Table. 
Table. Results. Changes in Encounters per Day Associated with the COVID-19 Pandemic

\section{A. Base-Case Analysis (Assuming No Lag)}

\begin{tabular}{|c|c|c|c|c|c|c|c|c|}
\hline \multirow[b]{2}{*}{ Condition } & \multirow[b]{2}{*}{ Year } & \multicolumn{2}{|c|}{ January-February } & \multicolumn{2}{|c|}{ March-April ${ }^{+}$} & \multirow{2}{*}{$\begin{array}{c}\text { IRR, }{ }^{\ddagger} \\
\text { March-April compared } \\
\text { with January-February } \\
(95 \% \mathrm{Cl})\end{array}$} & \multirow{2}{*}{$\begin{array}{l}\text { Difference-in- } \\
\text { Differences Estimate, } \$ \\
\text { Ratio of IRR in } 2020 \text { to } \\
\text { IRR in } 2019 \\
(95 \% \mathrm{Cl})\end{array}$} & \multirow[b]{2}{*}{$\begin{array}{c}\mathrm{p}- \\
\text { value }\end{array}$} \\
\hline & & $\begin{array}{l}\text { Number of } \\
\text { encounters }\end{array}$ & $\begin{array}{c}\text { Incidence rate, } * \\
\text { encounters per day } \\
(95 \% \mathrm{Cl})\end{array}$ & $\begin{array}{l}\text { Number of } \\
\text { encounters }\end{array}$ & $\begin{array}{c}\text { Incidence rate, }{ }^{*} \\
\text { encounters per day } \\
(95 \% \mathrm{Cl})\end{array}$ & & & \\
\hline \multicolumn{9}{|c|}{ Hospitalizations for Acute Cardiovascular Conditions } \\
\hline \multicolumn{9}{|c|}{ Myocardial Infarction } \\
\hline & 2019 & 141 & $2.39(2.07-2.76)$ & 93 & $2.02(1.69-2.42)$ & $0.85(0.67-1.07)$ & $0.67(0.46-0.97)$ & 0.04 \\
\hline & 2020 & 111 & $1.85(1.57-2.18)$ & 48 & $1.04(0.81-1.34)$ & $0.56(0.42-0.76)$ & & \\
\hline \multicolumn{9}{|l|}{ Stroke } \\
\hline & 2019 & 114 & $1.81(1.52-2.16)$ & 74 & $2.11(1.70-2.63)$ & $1.17(0.88-1.55)$ & $0.42(0.28-0.65)$ & $<0.001$ \\
\hline & 2020 & 153 & $2.43(2.09-2.83)$ & 42 & $1.20(0.90-1.60)$ & $0.49(0.36-0.68)$ & & \\
\hline
\end{tabular}

\section{Referrals for New Cancer Diagnosis}

Breast Cancer

$\begin{array}{llllll}2019 & 42 & 0.72(0.45-1.12) & 48 & 0.79(0.52-1.20) & 1.11(0.59-2.05) \\ 2020 & 49 & 0.82(0.54-1.24) & 36 & 0.61(0.37-0.99) & 0.75(0.39-1.42\end{array}$

Hematologic

Cancer

$\begin{array}{llllll}2019 & 77 & 1.31(0.92-1.85) & 81 & 1.33(0.94-1.87) & 1.02(0.62-1.66) \\ 2020 & 72 & 1.20(0.84-1.73) & 50 & 0.85(0.55-1.31) & 0.71(0.40-1.24)\end{array}$




\section{B. Sensitivity Analysis (Assuming a One-Month Lag for Referrals for New Cancer Diagnoses)}

\begin{tabular}{|c|c|c|c|c|c|c|c|c|}
\hline \multirow[b]{2}{*}{ Condition } & \multirow[b]{2}{*}{ Year } & \multicolumn{2}{|c|}{ January-March } & \multicolumn{2}{|r|}{ April } & \multirow{2}{*}{$\begin{array}{c}\text { IRR, }+ \\
\text { April compared with } \\
\text { January-March } \\
(95 \% \mathrm{Cl})\end{array}$} & \multirow{2}{*}{$\begin{array}{l}\text { Difference-in- } \\
\text { Differences Estimate, } \neq \\
\text { Ratio of IRR in } 2020 \text { to } \\
\text { IRR in } 2019 \\
(95 \% \mathrm{Cl})\end{array}$} & \multirow[b]{2}{*}{$\begin{array}{c}p- \\
\text { value }\end{array}$} \\
\hline & & $\begin{array}{l}\text { Number of } \\
\text { encounters }\end{array}$ & $\begin{array}{c}\text { Incidence rate, } * \\
\text { encounters per day } \\
(95 \% \mathrm{Cl})\end{array}$ & $\begin{array}{l}\text { Number of } \\
\text { encounters }\end{array}$ & $\begin{array}{c}\text { Incidence rate, } * \\
\text { encounters per day } \\
(95 \% \mathrm{Cl})\end{array}$ & & & \\
\hline \multicolumn{9}{|c|}{ Breast Cancer } \\
\hline & 2019 & 66 & $0.73(0.63-0.85)$ & 24 & $0.80(0.63-1.02)$ & $1.09(0.82-1.44)$ & $0.35(0.21-0.58)$ & $<0.001$ \\
\hline & 2020 & 76 & $0.84(0.73-0.96)$ & 9 & $0.32(0.22-0.48)$ & $0.38(0.25-0.58)$ & & \\
\hline \multicolumn{9}{|c|}{ Hematologic } \\
\hline & 2019 & 111 & $1.23(1.04-1.46)$ & 47 & $1.57(1.21-2.03)$ & $1.27(0.93-1.73)$ & $0.39(0.22-0.68)$ & $<0.001$ \\
\hline & 2020 & 106 & $1.16(0.98-1.38)$ & 16 & $0.57(0.37-0.89)$ & $0.49(0.31-0.79)$ & & \\
\hline
\end{tabular}

* The incidence rate was estimated by dividing the number of encounters in a given time priod by the number of days in the time period; the $95 \%$ confidence interval ( $\mathrm{Cl}$ ) was constructed by fitting a Poission regression model with the dispersion parameter estimated by deviance

† The most recent data available varied by condition in the year 2020: April $6^{\text {th }}$ for stroke, April $15^{\text {th }}$ for myocardial infarction, and April $28^{\text {th }}$ for malignancies. Events were censored at these dates for both 2019 and 2020 data to ensure equal ascertainment between years.

¥ Incidence rate ratio (IRR) was calculated from a Poisson regression comparing the number of encounters in the subsequent period (e.g., March-April) in a given year to the number of encounters in the prior period (e.g., January-February).

$\S$ The difference-in-differences estimate is the ratio of the IRR in 2020 to the IRR in 2019 and can be interpreted as the proportional reduction in events during the pandemic, adjusted for prior trends. 


\section{References}

1. COVID-19 Guidance and Directives. Commonwealth of Massachusetts website. Available at https://www.mass.gov/info-details/covid-19-guidance-and-directives. Accessed on April 29, 2020.

2. De Filippo O, D'Ascenzo F, Angelini F, et al. Reduced Rate of Hospital Admissions for ACS during Covid-19 Outbreak in Northern Italy. N Engl J Med 2020. Available at https://www.nejm.org/doi/full/10.1056/NEJMc2009166. Accessed on April 30, 2020.

3. Garcia S, Albaghdadi MS, Meraj PM, et al. Reduction in ST-Segment Elevation Cardiac Catheterization Laboratory Activations in the United States during COVID-19 Pandemic. J Am Coll Cardiol 2020:27259.

4. U.S. Coronavirus Death Toll Is Far Higher Than Reported, C.D.C. Data Suggests. The New York Times. Available at https://www.nytimes.com/interactive/2020/04/28/us/coronavirus-death-toll-total.html. Accessed on April 28, 2020.

5. Mehrotra A, Chernew M, Linetsky D, Hatch H, and Cutler D. What Impact Has COVID19 Had on Outpatient Visits? The Commonwealth Fund website.

https://www.commonwealthfund.org/publications/2020/apr/impact-covid-19-outpatientvisits. April 23, 2020. Accessed on April 29, 2020. 